\title{
Siostrzane losy
}

\begin{abstract}
Sister fates
Summary: The author presents the common beginnings and 60 years of cooperation between the Chair of Linguistic Didactics and Polish Literature at the Higher School of Pedagogy in Katowice (and later at the University of Silesia) and the Chair of Polish Literature and Language Didactics at the Higher School of Pedagogy in Cracow (currently at the Pedagogical University in Cracow). Using the "family" metaphor (the sister departments), the author describes the relationships between the two units and the joint activities and the researchers who inspire these activities.

Keywords: Chair of Linguistic Didactics and Polish Literature at the University of Silesia in Katowice, language didactics, Polish literature didactics
\end{abstract}

Dydaktykę literatury i języka polskiego na Uniwersytecie Śląskim w Katowicach oraz na Uniwersytecie Pedagogicznym im. KEN w Krakowie można najkrócej opisać za pomocą figury dwóch sióstr, córek jednej matki, które założyły własne rodziny, gdy doszły do pełnoletniości, ale stale utrzymują bliskie więzi rodzinne i są wierne zobowiązaniom wynikającym z tych więzi.

Matką było przedwojenne Państwowe Pedagogium w Krakowie oraz Instytut Pedagogiczny w Katowicach, założone w 1928 roku (oba z językiem polskim w programach studiów) ${ }^{1}$. Te placówki reaktywowano w roku 1944, by następnie przekształcić je w państwowe wyższe szkoły pedagogiczne (Zarządzenie Ministra Oświaty z 12.03.1946 r.). W Krakowie pracami nad organizacją uczelni kierował Profesor Stefan Szuman, w Katowicach — Profesor Józef Pieter. Pla-

${ }^{1}$ Zob. W. Zarembina: Powstanie i rozwój Wyższej Szkoty Pedagogicznej w Katowicach. W: Wyższa Szkoła Pedagogiczna w Katowicach 1950-1968. Red. A. Jarosz, A. Jendrysik. Katowice 1971, s. 11-21. 
cówka katowicka została wkrótce połączona z uczelnią łódzką, ale wznowiła działalność w roku 1950, by od 1968 roku zyskać status uniwersytetu. Na obu uczelniach istniał Wydział Humanistyczny, a w jego ramach kierunek filologia polska, którego składowymi częściami stały się katedry metodyki literatury i języka polskiego. Obie uczelnie wyrastały z doświadczeń Uniwersytetu Jagiellońskiego oraz z przedwojennych koncepcji akademickiego przygotowania nauczycieli, w tym - nauczycieli języka polskiego dla szkół powszechnych i średnich; obie też opierały kadrę akademicką na uczonych, którzy mieli duże doświadczenie jako nauczyciele praktycy i którzy dobrze zdawali sobie sprawę z konieczności przygotowywania przyszłych pedagogów szkolnych, wiążąc w kształceniu teorie dydaktyczne oraz rozbudowane systemy praktyk. Można więc mówić o łączących nasze placówki tradycjach rodzinnych, o powinowactwie kadrowym oraz o wspólnych korzeniach, z których wyrósł etos zawodowy z nieodłącznym elementem praktyki jako obligatoryjnym składnikiem przygotowania zawodowego na specjalności nauczycielskiej.

Metodyka literatury i języka polskiego w katowickiej WSP (dziś Uniwersytecie Śląskim) oraz krakowskiej WSP (dziś Uniwersytecie Pedagogicznym) wypracowały swoje profile w zakresie badań naukowych oraz dydaktyki w szkole wyższej, kontynuując nurt nowoczesnej metodyki zapoczątkowany w dwudziestoleciu międzywojennym. W Krakowie działał Zakład Metodyki Literatury Polskiej (od 1955 roku), następnie Katedra Metodyki Nauczania Języka Polskiego i Literatury Polskiej (od 1958 roku). W tym samym roku w Katowicach powstała analogiczna jednostka: najpierw Zakład Metodyki Nauczania Literatury i Języka Polskiego (w 1958 roku), a rok później — Katedry Metodyki (1.10.1959 roku). Jak to siostry - zawsze razem... Obie placówki miały swoich liderów. W Katowicach była to Mieczysława Mitera-Dobrowolska, w Krakowie - Władysław Szyszkowski. Oni tworzyli zręby studiów i badań, z kręgu ich zainteresowań, koncentrujących się zwłaszcza na modelu lektury szkolnej, która jest nakierowana na strukturę tekstu traktowanego jednocześnie jako przekaz aksjologiczno-formacyjny, wyrosły następne generacje uczonych. Niemal nie do uwierzenia, że uczniowie tych naszych liderów-założycieli dziś mają status „stypendystów ZUS”...

Między dwiema placówkami żywa była współpraca zarówno instytucjonalna oraz programowa, jak i personalna. Pod kierunkiem Docent doktor Mieczysławy Mitery-Dobrowolskiej powstała np. w roku 1984 praca doktorska Marii Puzerewicz-Kaczmarek Koncepcje nauczania literatury polskiej $w$ wyższych klasach gimnazjów galicyjskich w pięćdziesięcioleciu 1867-1918 (dyskusje i polemiki). Ten przewód doktorski był jednak prowadzony na Wydziale Humanistycznym WSP w Krakowie. Inny przykład związków wzajemnych, personalnych i naukowych: oto nieżyjący już mój dawny nauczyciel akademicki Profesor Mieczysław Łojek doktorat z metodyki obronił w 1970 roku na Uniwersytecie Śląskim pod kierunkiem Profesor Mitery-Dobrowolskiej (jak bardzo ją cenił, 
świadczy książka jego autorstwa Mieczysława Mitera-Dobrowolska. Wzór polonistki na dziś i na jutro) $)^{2}$. Łojek, uczeń Dobrowolskiej, badaczki z Uniwersytetu Śląskiego, habilitował się w roku 1977 w krakowskiej WSP. Zawodowo był związany z Olsztynem i Bydgoszczą, przenosząc na północ Polski te doświadczenia, które zdobył w Katedrze Metodyki Nauczania Literatury i Języka Polskiego w Katowicach oraz w Katedrze Metodyki Nauczania Języka Polskiego i Literatury Polskiej w Krakowie ${ }^{3}$.

Wzajemne związki personalne oraz wymiana kadr między naszymi placówkami były głębokie: do krakowskiej WSP przenieśli się dydaktycy literatury: Zofia i Jan Polakowscy. Jan Polakowski, wraz z Zenonem Urygą, tworzyli metodologiczne podstawy autonomicznej subdyscypliny badawczej: dydaktyki literatury i języka polskiego. Już nie warsztatowo i praktycystycznie pojmowana „metodyka”, lecz akademicka „dydaktyka”. Wiele trudu kosztowało kolejnych kierowników katedr, dziekanów wydziałów i rektorów obu uczelni przełamanie oporu konserwatywnych kolegów z innych uczelni i uregulowanie prawne statusu akademickiego doktoratów, a następnie habilitacji, z zakresu dydaktyki literatury czy dydaktyki języka jako nauk humanistycznych, a nie pedagogicznych. Profesorowie: Jan Polakowski, Zenon Uryga, Edward Polański i Bożena Chrząstowska (z Poznania) czy Mieczysław Inglot (z Wrocławia) to najczynniejsi rycerze $w$ tych zmaganiach $z$ urzędami, ale i z oporem środowisk uniwersyteckich. Ten etap rozwoju naszej dyscypliny w kraju — w latach siedemdziesiątych i osiemdziesiątych - oprócz intensywnych kontaktów naukowych i redakcyjnych spajał środowisko dydaktyków, a tym samym aktywizował je badawczo.

Autonomia akademicka subdyscypliny stała się widoczna dla każdego, kiedy zaczęły się ukazywać zeszyty i roczniki periodyków naukowych, które ogłaszały wyniki badań empirycznych i koncepcje teoretyczne dotyczące dydaktyki literatury i języka. W Krakowie cyklicznie wydawano tematyczne numery „Rocznika Naukowo-Dydaktycznego”. W Katowicach tytuł periodyku sformułowano może bardziej twórczo, gdyż zaczęto wydawać wydawnictwo ciągłe „Z Teorii i Praktyki Dydaktycznej Języka Polskiego” (od 1977 roku) ${ }^{4}$. Wymiana autorów publikujących w tych pismach dodatkowo zacieśniała więzy instytucjonalne $\mathrm{i}$ osobiste, które następnie przybrały formę wzajemnej pomo-

${ }^{2}$ M. Łojek: Mieczysława Mitera-Dobrowolska. Wzór polonistki na dziś i na jutro. Bydgoszcz 1998.

3 Takich powiązań odnotowano w historii obu Katedr więcej, np.: pod kierunkiem Profesora Zenona Urygi, badacza z krakowskiej katedry, pracę doktorską (pt. Recepcja liryki młodopolskiej w szkole średniej) napisała i obroniła dr hab. Ewa Ogłoza z Uniwersytetu Śląskiego, a z kolei pod opieką naukową Profesor Heleny Synowiec z jednostki katowickiej pracę doktorską obroniła dr hab. Marta Potaś-Szymańska, prof. UP w Krakowie.

${ }^{4}$ Poprzedzone dwoma tomami cyklu $Z$ pomoca poloniście ( $Z$ pomoca poloniście 1 . Red. M. Mitera-Dobrowolska. Katowice 1963; Z pomoca poloniście 2. Red. M. Mitera-Dobrowolska. Katowice 1968). 
cy w przygotowaniu młodej kadry akademickiej. Chodzi o staże naukowe oraz przewody doktorskie i habilitacyjne. Tak się złożyło, że przez czas jakiś ośrodek krakowski był zasobny w dydaktyków literaturoznawców przy jednoczesnym niedoborze dydaktyków języka. Nasi pracownicy: Bogusław Skowronek i Marta Szymańska właśnie dzięki pomocy siostry z Katowic mogli zdobyć stopnie naukowe z dydaktyki języka. Wielki, wręcz nieoceniony był tu osobisty wkład Profesorów: Edwarda Polańskiego i Heleny Synowiec. Ale i inni pracownicy obu siostrzanych katedr wielokrotnie bywali recenzentami w przewodach prowadzonych na obu uczelniach; bywali też współautorami publikacji naukowych i dydaktycznych. Mieliśmy do siebie zaufanie, wiedzieliśmy, że słabsze strony recenzowanych rozpraw zostaną na pewno wydobyte i ocenione tak, jak na to zasługują, jednocześnie mieliśmy pewność, że nowatorskie - a nawet w tym nowatorstwie ryzykowne - koncepcje zostaną potraktowane jako dowody autentycznych badawczych pasji i dążenia do prawdy. Na drodze do prawdy można popełnić błąd młodzieńczej gorliwości i zapału, ale obiektywna kontrola i życzliwa porada pomogą (i pomagały) odnaleźć właściwy tor. Sprzyjały temu i recenzje awansowe, i koleżeńskie dyskusje choćby z okazji cyklicznie organizowanych w Krakowie spotkań z cyklu Jesienna Szkoła Dydaktyków czy katowickich konferencji o dydaktyce polonistycznej oraz literaturze dla dzieci i młodzieży. Na referentów i dyskutantów z Uniwersytetu Śląskiego w Katowicach, na Profesorów Ewę Jaskółę, Bernadetę Niesporek-Szamburską i całą rodzinę z siostrzanej katedry katowickiej, zawsze mogliśmy liczyć. O Profesorze Polańskim nie muszę wspominać, bo on - jako doktor honoris causa krakowskiej uczelni — jest i Wasz, i nasz...

Sześćdziesiąt lat to wiek, kiedy już się wiele potrafi, a jeszcze ma się dość siły, aby sięgać ku gwiazdom po nowe prawdy naukowe. Po to żyjemy, po to weszliśmy na drogę zawodową, którą wytyczali założyciele naszych placówek. Z okazji tej rocznicy krakowska szkoła dydaktyki literatury i języka polskiego życzy swojej katowickiej siostrze, aby nigdy nie ustawała w ochocie do pracy dla dobra polskiej humanistyki i polskiej szkoły. I aby z tej pracy każdego dnia odczuwała zasłużoną satysfakcję.

\section{Bibliografia}

Łojek M.: Mieczysława Mitera-Dobrowolska. Wzór polonistki na dziś i na jutro. Bydgoszcz 1998. Z pomoca poloniście 1. Red. M. Mitera-Dobrowolska. Katowice 1963.

Z pomoca poloniście 2. Red. M. Mitera-Dobrowolska. Katowice 1968.

Zarembina W.: Powstanie i rozwój Wyższej Szkoły Pedagogicznej w Katowicach. W: Wyższa Szkota Pedagogiczna w Katowicach 1950 - 1968. Red. A. Jarosz, A. Jendrysik. Katowice 1971. 